\title{
Applications of Bayesian Networks as Decision Support Tools for Water Resource Management under Climate Change and Socio-Economic Stressors: A Critical Appraisal
}

\author{
Thuc D. Phan ${ }^{1,2, *}$, James C. R. Smart ${ }^{3}\left(\mathbb{D}\right.$, Ben Stewart-Koster ${ }^{3}$, Oz. Sahin ${ }^{4} \mathbb{D}^{\circ}$, \\ Wade L. Hadwen ${ }^{3}$ D, Lien T. Dinh ${ }^{5}$, Iman Tahmasbian ${ }^{6}$ id and Samantha J. Capon ${ }^{3}$ \\ 1 Department for Management of Science and Technology Development, Ton Duc Thang University, \\ Ho Chi Minh City 758307, Vietnam \\ 2 Faculty of Environment and Labour Safety, Ton Duc Thang University, Ho Chi Minh City 758307, Vietnam \\ 3 Australian Rivers Institute, Griffith School of Environment and Science, Griffith University, Nathan, \\ Queensland 4111, Australia; j.smart@griffith.edu.au (J.C.R.S.); B.Stewart-Koster@griffith.edu.au (B.S.-K.); \\ w.hadwen@griffith.edu.au (W.L.H.); s.capon@griffith.edu.au (S.J.C.) \\ 4 Griffith School of Engineering and Built Environment, Griffith University, Gold Coast, \\ Queensland 4215, Australia; o.sahin@griffith.edu.au \\ 5 Griffith Business School, Griffith University, Nathan, Queensland 4111, Australia; 1.dinh@griffith.edu.au \\ 6 Department of Agriculture and Fisheries, Toowoomba, Queensland 4350, Australia; \\ Iman.tahmasbian@daf.qld.gov.au \\ * Correspondence: phanduythuc@tdtu.edu.vn; Tel.: +84945697106
}

Received: 29 October 2019; Accepted: 11 December 2019; Published: 14 December 2019 updates

\begin{abstract}
Bayesian networks (BNs) are widely implemented as graphical decision support tools which use probability inferences to generate "what if?" and "which is best?" analyses of potential management options for water resource management, under climate change and socio-economic stressors. This paper presents a systematic quantitative literature review of applications of BNs for decision support in water resource management. The review quantifies to what extent different types of data (quantitative and/or qualitative) are used, to what extent optimization-based and/or scenario-based approaches are adopted for decision support, and to what extent different categories of adaptation measures are evaluated. Most reviewed publications applied scenario-based approaches $(68 \%)$ to evaluate the performance of management measures, whilst relatively few studies $(18 \%)$ applied optimization-based approaches to optimize management measures. Institutional and social measures $(62 \%)$ were mostly applied to the management of water-related concerns, followed by technological and engineered measures (47\%), and ecosystem-based measures (37\%). There was no significant difference in the use of quantitative and/or qualitative data across different decision support approaches $(p=0.54)$, or in the evaluation of different categories of management measures $(p=0.25)$. However, there was significant dependence $(p=0.076)$ between the types of management measure(s) evaluated, and the decision support approaches used for that evaluation. The potential and limitations of $\mathrm{BN}$ applications as decision support systems are discussed along with solutions and recommendations, thereby further facilitating the application of this promising decision support tool for future research priorities and challenges surrounding uncertain and complex water resource systems driven by multiple interactions amongst climatic and non-climatic changes.
\end{abstract}

Keywords: climate change; decision support tools; optimization-based approaches; scenario-based approaches; management measure categories; socio-economic stressors 


\section{Introduction}

\subsection{Contextual Background}

Water resource systems are widely regarded as being under considerable threat in many regions across the world, often from the combined pressures of climate change, socio-economic stressors, and demands from multiple stakeholders [1]. Changes in precipitation, increased temperature and sea-level rise are major drivers of changes in water availability and water demand in these systems [2]. Interactions among these climatic drivers coupled with population growth and urbanization can lead to water scarcity, making it increasingly challenging for managers to satisfy growing water demands from multiple water users [3]. Where water resources are insufficient to supply socio-economic development and ecosystem functions, competitive behaviour among water use sectors can result [1], with considerable potential for conflict [3]. In such circumstances, it is important to identify appropriate, effective and efficient adaptive responses to alleviate these potential conflicts, and inform judicious trade-offs between competing demands [4].

Potential adaptation options have to be evaluated carefully to ensure that they are feasible, effective and efficient [5] as well as to avoid mal-adaptation, reduce risks, and the introduction of unnecessary intervention costs [6]. Adaptation measures for water resource management can take many different forms, depending on the context and objectives of a particular situation, so it is not surprising that several different approaches have been used to categorize the diversity of adaptation options and to assess their performance [4]. Adaptation options are frequently evaluated in terms of their costs, effectiveness, robustness and resilience across a range of current and anticipated future scenarios [5] for key physical, social, economic, and environmental drivers of the affected water resource system [7]. However, it is difficult to configure a consistent evaluation framework to support adaptation decision making for water resource management, because predicting the current and future responses of water resource systems to changes in multiple interacting drivers involves high levels of uncertainty and complexity. Given these challenges, evaluation approaches are needed, that can integrate empirical data, model simulations, and expert knowledge to facilitate selection of cost-effective, robust and resilient adaptation options within situational and budgetary constraints.

Bayesian networks (BNs) hold considerable promise as decision support tools for evaluating adaptation options for water resource management [8]. BNs can be configured as graphical decision support tools which use probability inference to generate "what if?" and "which is best?" analyses of potential adaptation options for water resource management, under climate change and socio-economic stressors [6]. A particular advantage of using BNs to inform water resource management is their capacity to integrate both quantitative data (e.g., field data and modelling results) and qualitative data (e.g., expert knowledge and stakeholder beliefs) to generate probabilistic predictions about the outcomes of potential adaptation options or policies [9]. The generation of probabilistic predictions is extremely valuable in devising management responses to scenarios of climate change and socio-economic development, which themselves come with an associated probability [6]. In addition, the ability of BNs to incorporate expert knowledge is particularly helpful for considering the uncertainty inherent in complex water resource systems, and for estimating costs and relative utilities of adaptation outcomes $[6,8]$.

Several papers have reviewed applications of BNs in the broad context of environmental and water resource management. For example, Aguilera et al. [10] focused on the usage of BNs for modelling and informing the management of environmental systems generally. McDonald et al. [11] reviewed the usage of BNs in ecological risk assessments in freshwater and estuarine ecosystems, while Sperotto et al. [12] investigated the usage of BNs in climate change impact assessment for environmental management. Additionally, Phan et al. [13] reviewed the applications of BNs in water resource management across different water management domains and geographical locations, as well as considering the application of different knowledge bases for BN development. However, to date, no 
reviews have evaluated the application of BNs as decision support tools for identifying appropriate adaptation options for water resource management under climate change and socio-economic stressors.

This paper presents the findings of a systematic quantitative literature review conducted to explore the applications of $\mathrm{BNs}$ as decision support tools for managing water resource under threats from climate change and socio-economic stressors. The review examines the different types of data (quantitative and/or qualitative) that have been used, whether optimization-based and/or scenario-based approaches are adopted for decision making support, and the different categories of adaptation measures evaluated in BNs for water resource management. Gaps are identified in the application of particular decision support approaches for evaluating different types of adaptation measures. Potential reasons for observed patterns of usage are suggested, and potential risks are discussed. Finally, possible solutions are suggested to enhance the efficacy of BNs for decision support in water resource management.

\subsection{Bayesian Networks}

A Bayesian network (BN) is a probabilistic graphical model consisting of a directed acyclic graph (DAG), which denotes dependencies and independencies between variables, and conditional probability tables (CPTs), which specify the relationships between those variables [9]. Each variable, defined as a node in the BN, has a set of states, and the probability of each state of a node is dependent on the states of the parent node(s). These probabilities are defined by the CPTs, which may be derived using qualitative and/or quantitative data [14]. Quantitative data refers to the measurable characteristics or fluxes in a system, and may include time-series data, such as river discharge, spatial data, such as household census data and the population within a region, or point data such as water quality conditions. Qualitative data or information includes expert opinion, stakeholder beliefs or some types of information derived from surveys and interviews [15].

There are three possible types of nodes in a BN: Chance or nature nodes, decision nodes and utility nodes which can be either discrete or continuous [9]. The BN can be used as a Decision Support Tool (DST) when decision nodes (management options) and utility nodes (costs and benefits of actions and outcomes) are included [16]. The DST can be applied to generate 'which is best?' (optimization-based) or 'what if?' (scenario-based) analyses of the performance of water resource management options [6]. The states of decision nodes can be used to depict possible management options. Decision nodes can also have an associated cost function that reports the actual or relative cost incurred in implementing each management option [9]. The states of response or target nodes(s) in the system can be used to depict different possible outcomes from implementing particular management options. Response nodes can have an associated utility function that reports the value (or utility) consequences which follow from each possible outcome state. Probabilities for the different outcome states under a particular management option follow from the inter-linkages between system variables as specified in the system's CPTs. Value (or utility) consequences for the different outcomes can be specified in monetary or relative performance terms, reflecting their desirability [16]. The value delivered by implementing a particular management option can thus be expressed as the probability-weighted sum of the values (or utilities) of the different possible outcomes under that management option. From an economics perspective, this probability-weighted sum could be termed the expected utility delivered by the management option. If value consequences are expressed in monetary terms, a probability-weighted monetary benefit can also be calculated.

A BN which includes the decision node(s), and associated cost node(s), together with the response node(s) and associated utility node(s), can be considered as an optimization-based decision support tool (Figure 1a), because it can identify the management option which delivers the highest probability-weighted value relative to the cost incurred [9]. This BN configuration could provide a probabilistic cost and benefit-based optimization. Probabilistic cost-effectiveness of different management options can be evaluated by a BN with decision node(s), cost node(s), and a response node (without an associated utility node), by dividing the probability-weighted physical outcome (e.g., water availability in Figure 1a) for each management option by the cost of implementing that option [9]. 
Equivalent optimization functionality can be obtained by coupling a BN with decision node(s) and a response node, but without a cost or utility node, to external estimation of the economic costs of management options (for cost-effectiveness analysis), or to economic estimations of management costs, and economic valuations of the different output states (for cost-benefit analysis) (e.g., [17,18]). In contrast, a BN which only includes a decision node(s) and response node(s), without associated cost nodes and/or the utility node(s) - and without any coupling to external economic cost or value estimations - can be considered to provide scenario-based decision-making support, because it can evaluate probability-weighted physical outcome(s) (e.g., water availability in Figure 1b) for different management options, under different scenarios for key drivers of the system. However, a BN which does not include decision node(s), cost node(s) and/or utility node(s), and/or not scenarios can be considered as a predictive model only.

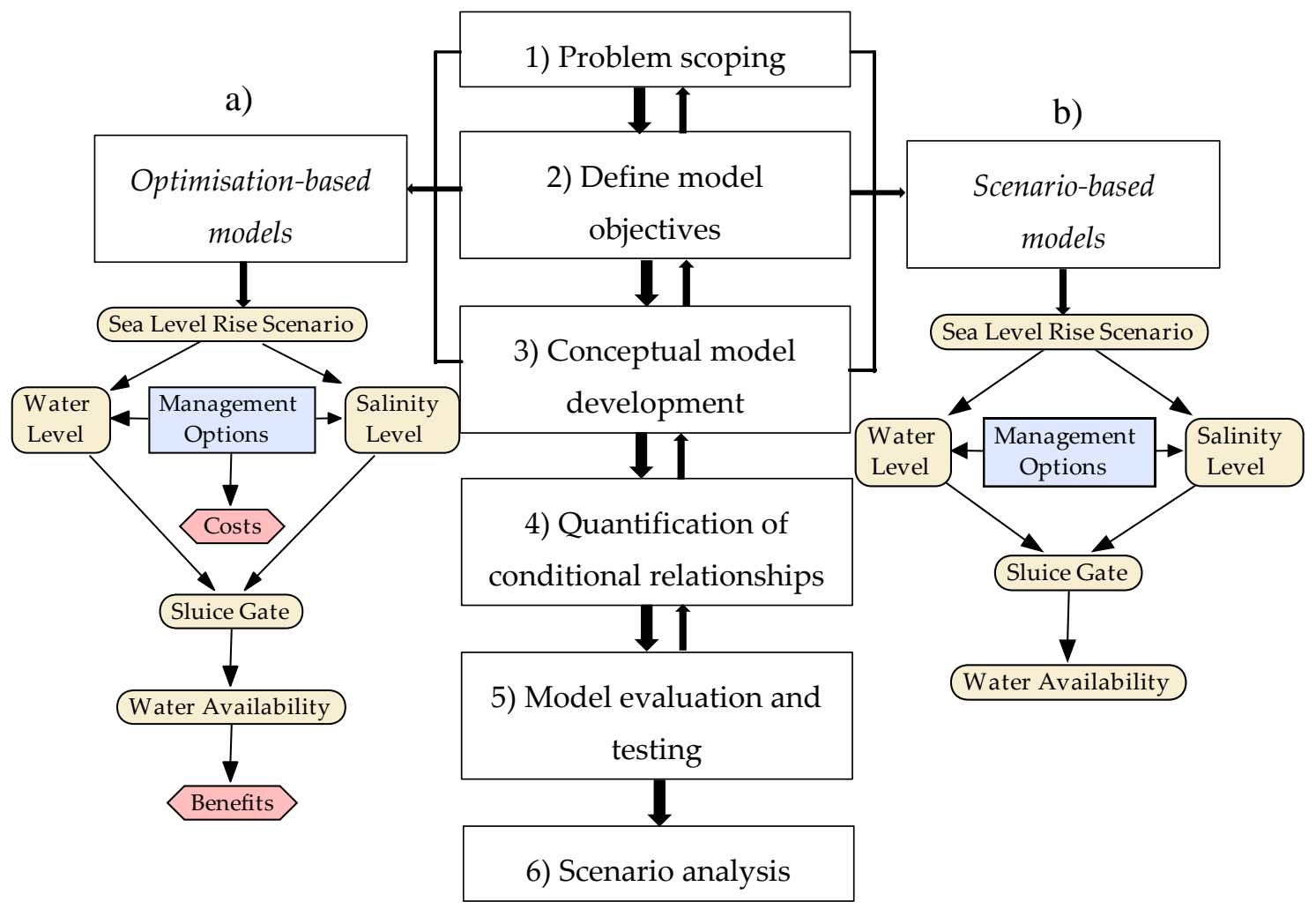

Figure 1. Main steps in developing a Bayesian network (BN) (adapted from Ames et al. [16], Bromley et al. [19], Ticehurst et al. [20]), and an example BN configured for: (a) Optimization-based decision support, featuring a decision node (coloured blue) with an associated cost node indicating the costs for implementing the different management options, and a benefit node indicating the desirability of the different states of water availability which result at the output node; (b) scenario-based decision support, featuring a decision node without the associated cost node, and an output node without an associated benefit node.

These different modelling approaches can be constructed using six iterative steps (Figure 1), to produce a valid and useful $\mathrm{BN}$ for decision-making support:

(1) Problem scoping: Identify challenges confronting the management of water systems by collecting and analysing historical data on key drivers to understand problems in the systems under study.

(2) Define model objectives: Identify the aim of the model (e.g., optimisation of appropriate management measures, or understanding relationships among key variables of the system) and select stakeholders to involve in the modelling process. 
(3) Conceptual model development: Identify the important system variables (including management measures and their attribute values) and their relationships in the system. Identification of this information may be based on a literature review, historical data analysis, and consultation with stakeholders.

(4) Quantification of conditional relationships: Assign states and probabilities to each variable in the system using historical data, other modelling results, and elicitation from stakeholders.

(5) Model evaluation and testing: The model can be evaluated and tested using quantitative methods (e.g., sensitivity analysis and assessments of predictive accuracy) and/or qualitative methods (e.g., feedback from experts).

(6) Scenario analysis: BNs can be used as decision support tools because they allow an assessment of the probability of changes in the states of response or target nodes in the system, associated with management measures or scenarios contained in the model.

\section{Methods}

\subsection{Systematic Quantitative Literature Review}

An appraisal of BN applications for supporting decision-making in water resource management was conducted by undertaking a systematic quantitative review of relevant English language academic articles in three electronic databases (Web of Science, Scopus, and Google Scholar). Relevant articles (up to June 2019) were extracted from these databases by using a combination of ('BN model', 'Bayesian", 'Bayesian belief networks', or 'Bayesian networks', or 'Bayesian decision networks', or 'BBNs', or 'BNs') and change related search terms ('water"', or 'water resources', or 'river'). The wildcard $\left({ }^{*}{ }^{\prime \prime}\right)$ was used for Bayesian and Water to match all words around these two keywords. The title, abstracts and keywords of articles were included in these searches. Books or book chapters, review papers, conference proceedings and purely theoretical articles were not considered in this review.

The resulting database of academic research papers reporting on $\mathrm{BN}$ applications in decision-making supports for water resource management was then attributed according to the following fields: (a) The research aims of reviewed studies, (b) the types of data used in BN development for identifying adaptation options (quantitative or/and qualitative data), (c) consideration of climate change impacts (e.g., changes in sea level rise, precipitation and temperature) and socio-economic stressors (e.g., population growth and changes in agricultural and industrial production) on water resource management, (d) the basis for informing decision support (optimization-based or scenario-based), and (e) the types of adaptation measures considered (institutional and social measures; technological and engineered measures, and ecosystem-based measures).

The categorization of the types of adaptation options considered in the reviewed $\mathrm{BN}$ papers follows that used in the report of Intergovernmental Panel on Climate Change (IPCC) in 2014 [4]. This categorization is used here because climate change and socio-economic stressors are major drivers of the need for adaptation in the management of water resource systems worldwide. It is important to be clear that adaptation measures, as responses to stressor-induced changes, are distinct from any scenarios (e.g., population growth, sea-level rise) which might be applied to investigate the performance of those adaptation measures. The categories of adaptation options defined in the 2014 IPCC Report [4] are:

(i) Institutional and social measures: i.e., the inclusion of economic and social instruments, laws, regulations, policies and educational programs (e.g., water prices, water rights, and awareness raising)

(ii) Technological and engineered measures: i.e., the inclusion of technologies and methods (e.g., new crops, water-saving technology, irrigation efficiency technology), and constructions (e.g., desalination plants, wastewater treatment, reservoirs and rainwater tanks)

(iii) Ecosystem-based measures: i.e., the inclusion of green infrastructure and ecosystem services (e.g., forest cover, riparian planting and restoration) 


\subsection{Statistical Analysis}

Chi-square tests of independence were used to quantify whether there was a relationship between the types of data used, the types of management options considered and the decision-making approach of the BNs in the reviewed studies. The frequencies of each category of these variables were calculated for the analysis. Conducting the Chi-squared tests of independence for these variables aims to see the trend in the application of BNs as decision support tools for water resource management, under climate change and socio-economic development.

\section{Results}

A total of 819 relevant articles were initially identified from Scopus, Web of Science and Google Scholar after eliminating duplications. However, a perusal of the abstracts revealed that 686 of these articles did not specifically discuss the application of BNs to water resource management. The remaining shortlist of 133 articles was therefore examined in detail, to evaluate the application of BNs as decision-making support tools in water resource management (Table 1), to quantify the extent to which these applications used different data collection approaches to develop optimization- and scenario-based models, for the evaluation of different categories of management measures.

Table 1. List of reviewed applications of BNs as decision support tools for water resource management in the academic literature, published through to June 2019. QT: Quantitative data, QL: Qualitative data, ISM: Institutional and social measures: TEM: Technological and engineered measures: EM: Ecosystem-based measures: NO: No management measure consideration SC: Scenario-based decision making approaches, OP: Optimization-based decision making approaches, PR: Predictive only.

\begin{tabular}{|c|c|c|c|c|}
\hline Research Aims & Data Usage & Management Measures & Decision Making & Reviewed Studies \\
\hline \multirow{22}{*}{$\begin{array}{l}\text { Water quality } \\
\text { management }\end{array}$} & \multirow{3}{*}{ QL } & EM & SC, OP & McVittie et al. [21] \\
\hline & & \multirow{2}{*}{$\mathrm{NO}$} & SC & Joseph et al. [22] \\
\hline & & & PR & Tang et al. [23], Cheng et al. [24] \\
\hline & \multirow{9}{*}{ QT } & \multirow{2}{*}{ EM } & SC & Lee et al. [25], Moe et al. [26] \\
\hline & & & SC, OP & Sadoddin et al. [27] \\
\hline & & \multirow{2}{*}{ ISM } & OP & Mesbah et al. [17] \\
\hline & & & SC & Nikoo et al. [28] \\
\hline & & ISM, TEM, EM & SC & Forio et al. [29] \\
\hline & & TEM & SC & Hines and Landis [30] \\
\hline & & TEM, EM & $\mathrm{SC}, \mathrm{Op}$ & Said [31] \\
\hline & & \multirow[t]{2}{*}{$\mathrm{NO}$} & PR & $\begin{array}{l}\text { Ha and Stenstrom [32], Murray et al. [33], } \\
\text { Nikoo et al. [34], Park and Stenstrom [35], } \\
\text { Wang et al. [36], Liu et al. [37], Mayfield } \\
\text { et al. [38], Wijesiri et al. [39] }\end{array}$ \\
\hline & & & SC & $\begin{array}{l}\text { Dyer et al. [40], Liyanage and Yamada } \\
\text { [41], McLaughlin and Reckhow [42], } \\
\text { Nojavan et al. [43], Ramin et al. [44] }\end{array}$ \\
\hline & \multirow{10}{*}{ Both } & \multirow{2}{*}{ EM } & SC, OP & Keshtkar et al. [45] \\
\hline & & & SC & Lynam et al. [46] \\
\hline & & ISM & SC & Bertone et al. [47] \\
\hline & & \multirow{2}{*}{ ISM, EM } & SC & Dorner et al. [48], Ticehurst et al. [49] \\
\hline & & & $\mathrm{SC}, \mathrm{OP}$ & Rivers-Moore [1] \\
\hline & & ISM, TEM & SC & Reckhow [50] \\
\hline & & ISM, TEM, EM & SC & $\begin{array}{l}\text { Carpani and Giupponi [51], Holzkaemper } \\
\text { et al. [52] }\end{array}$ \\
\hline & & TEM, EM & SC, OP & Kragt et al. [53] \\
\hline & & \multirow{2}{*}{$\mathrm{NO}$} & SC & Hamilton et al. [54] \\
\hline & & & PR & Pollino et al. [14], Pike [55] \\
\hline
\end{tabular}


Table 1. Cont.

\begin{tabular}{|c|c|c|c|c|}
\hline Research Aims & Data Usage & Management Measures & Decision Making & Reviewed Studies \\
\hline \multirow{9}{*}{$\begin{array}{l}\text { Groundwater } \\
\text { management }\end{array}$} & QL & ISM, TEM & SC & $\begin{array}{c}\text { Giordano et al. [56], Roozbahani et al. } \\
\text { [57] }\end{array}$ \\
\hline & \multirow[b]{2}{*}{ QT } & TEM & SC & Aguilera et al. [58] \\
\hline & & NO & PR & $\begin{array}{c}\text { Fienen et al. [59], Nolan et al. [60], Shihab } \\
\text { [61], Moghaddam et al. [62] }\end{array}$ \\
\hline & \multirow{6}{*}{ Both } & ISM & SC & $\begin{array}{c}\text { Carmona et al. [63], Carmona et al. [64], } \\
\text { Henriksen et al. [65], Olalla et al. [66], } \\
\text { Subagadis et al. [67] }\end{array}$ \\
\hline & & ISM, EM & SC & Mohajerani et al. [68] \\
\hline & & \multirow{2}{*}{ ISM, TEM } & $\mathrm{OP}$ & Farmani et al. [69] \\
\hline & & & SC, OP & Molina et al. [70] \\
\hline & & \multirow{2}{*}{ NO } & PR & $\begin{array}{l}\text { Ghabayen et al. [71], Martín de Santa } \\
\text { Olalla et al. [72] }\end{array}$ \\
\hline & & & SC & $\begin{array}{l}\text { Henriksen et al. [73], Martinez-Santos } \\
\text { et al. [74] }\end{array}$ \\
\hline \multirow{11}{*}{$\begin{array}{l}\text { Water supply } \\
\text { management }\end{array}$} & QL & TEM & SC & Chan et al. [75] \\
\hline & \multirow{4}{*}{ QT } & ISM & SC & Pang and Sun [76], Avilés et al. [77] \\
\hline & & TEM & OP & $\begin{array}{l}\text { Ahmadi et al. [78], Bullene et al. [79], } \\
\text { Ghabayen et al. [80] }\end{array}$ \\
\hline & & \multirow[t]{2}{*}{ NO } & PR & $\begin{array}{l}\text { Francis et al. [81], Hunter et al. [82], Peng } \\
\text { et al. [83] }\end{array}$ \\
\hline & & & SC & [84] \\
\hline & \multirow{6}{*}{ Both } & ISM & SC & Dondeynaz et al. [85], Fisher et al. [86] \\
\hline & & \multirow{2}{*}{ TEM } & SC & Pagano et al. [87], Moglia et al. [88] \\
\hline & & & SC, OP & Moglia et al. [89] \\
\hline & & ISM, TEM, EM & $\mathrm{SC}$ & Noi and Nitivattananon [2] \\
\hline & & \multirow{2}{*}{ NO } & SC & Kabir et al. [90] \\
\hline & & & PR & Leu and Bui [91], Liedloff et al. [92] \\
\hline \multirow{10}{*}{$\begin{array}{l}\text { Irrigation } \\
\text { management }\end{array}$} & \multirow{3}{*}{ QL } & TEM & SC & Barron et al. [93] \\
\hline & & ISM, TEM, EM & SC & Cain et al. [94] \\
\hline & & NO & PR & Maleksaeidi et al. [95] \\
\hline & \multirow{3}{*}{ QT } & ISM & $\mathrm{SC}$ & Andriyas and McKee [96] \\
\hline & & TEM, EM & SC & Robertson and Wang [97] \\
\hline & & NO & SC & $\begin{array}{c}\text { Rahman et al. [98], Sherafatpour et al. } \\
\text { [99] }\end{array}$ \\
\hline & \multirow{4}{*}{ Both } & ISM & SC & Quinn et al. [100], Wang et al. [101] \\
\hline & & ISM, TEM & SC & Mamitimin et al. [102] \\
\hline & & TEM & OP & Batchelor and Cain [8] \\
\hline & & NO & PR & $\begin{array}{l}\text { Castelletti and Soncini-Sessa [103], } \\
\text { Saravanan [104] }\end{array}$ \\
\hline \multirow{10}{*}{$\begin{array}{l}\text { River related } \\
\text { management }\end{array}$} & \multirow{4}{*}{ QT } & \multirow{2}{*}{ EM } & SC & Johns et al. [105] \\
\hline & & & $\mathrm{SC}, \mathrm{OP}$ & Stewart-Koster et al. [106] \\
\hline & & ISM, TEM, EM & SC, OP & Hjerppe et al. [107] \\
\hline & & $\mathrm{NO}$ & SC & Leigh et al. [108], Shenton et al. [109] \\
\hline & \multirow{6}{*}{ Both } & EM & SC & $\begin{array}{l}\text { Allan et al. [110], Morrison and Stone } \\
\text { [111] }\end{array}$ \\
\hline & & TEM & SC & Calder et al. [112] \\
\hline & & TEM, EM & SC, OP & Borsuk et al. [113] \\
\hline & & ISM, EM & SC & Ropero et al. [114] \\
\hline & & \multirow{2}{*}{ NO } & PR & Chan et al. [115] \\
\hline & & & $\mathrm{SC}$ & Varis et al. [116] \\
\hline
\end{tabular}


Table 1. Cont

\begin{tabular}{|c|c|c|c|c|}
\hline Research Aims & Data Usage & Management Measures & Decision Making & Reviewed Studies \\
\hline \multirow{8}{*}{$\begin{array}{l}\text { Nutrient } \\
\text { management }\end{array}$} & QL & NO & PR & Tattari et al. [117] \\
\hline & \multirow{4}{*}{ QT } & ISM & SC & $\begin{array}{l}\text { Alameddine et al. [118], Couture et al. } \\
\text { [119] }\end{array}$ \\
\hline & & TEM & SC, OP & Ames et al. [16] \\
\hline & & TEM, EM & SC & Death et al. [7] \\
\hline & & NO & PR & $\begin{array}{l}\text { Qian and Miltner [120], Wijesiri et al. } \\
\text { [121] }\end{array}$ \\
\hline & \multirow{3}{*}{ Both } & ISM & $\mathrm{SC}$ & $\begin{array}{l}\text { Borsuk et al. [122], Borsuk et al. [123], } \\
\text { Nash and Hannah [124] }\end{array}$ \\
\hline & & ISM, TEM, EM & SC, OP & Barton et al. [6] \\
\hline & & $\mathrm{NO}$ & SC & McDowell et al. [125], Sperotto et al. [126] \\
\hline \multirow{8}{*}{$\begin{array}{c}\text { Water supply and } \\
\text { demand } \\
\text { management }\end{array}$} & \multirow{4}{*}{ QT } & \multirow{2}{*}{ ISM } & $\mathrm{SC}, \mathrm{OP}$ & Portoghese et al. [18] \\
\hline & & & SC & Sušnik et al. [127] \\
\hline & & ISM, TEM & SC & Asadilour et al. [128] \\
\hline & & $\mathrm{NO}$ & PR & Geraldi and Ghisi [129] \\
\hline & \multirow{4}{*}{ Both } & ISM & SC, OP & Molina et al. [130] \\
\hline & & ISM, TEM, EM & SC & Xue et al. [3] \\
\hline & & ISM, TEM & SC & Bromley et al. [19] \\
\hline & & $\mathrm{NO}$ & SC & Said et al. [131], Varis and Kuikka [132] \\
\hline \multirow{6}{*}{$\begin{array}{l}\text { Reservoir } \\
\text { management }\end{array}$} & \multirow{4}{*}{ QT } & ISM & SC & Mediero et al. [133] \\
\hline & & TEM & SC & Malekmohammadi et al. [134] \\
\hline & & \multirow{2}{*}{ NO } & SC & Ropero et al. [135] \\
\hline & & & PR & Kim et al. [136] \\
\hline & \multirow{2}{*}{ Both } & ISM & $\mathrm{SC}, \mathrm{OP}$ & Landuyt et al. [137] \\
\hline & & NO & PR & Chen et al. [138] \\
\hline $\begin{array}{l}\text { Wastewater } \\
\text { treatment } \\
\text { management }\end{array}$ & Both & NO & PR & Cheon et al. [139], Li et al. [140] \\
\hline $\begin{array}{c}\text { Water demand } \\
\text { management }\end{array}$ & Both & NO & PR & Inman et al. [141] \\
\hline $\begin{array}{l}\text { Water and energy } \\
\text { management }\end{array}$ & Both & ISM, TEM & SC, OP & Bertone et al. [142] \\
\hline
\end{tabular}

\subsection{Research Aims of the Reviewed Studies}

Ten different categories of research aims in water-related management were considered in the reviewed studies (Table 1). Water quality management was the major concern addressed by reviewed studies $(29 \%)$, followed by water supply management $(16 \%)$, groundwater management $(14 \%)$, nutrient management ( $8 \%$ ) and irrigation management $(8 \%)$. Water demand was less considered in the reviewed studies. Depending on the different research aims of these reviewed studies, the decision-making approaches and management measures were considered differently to achieve expected outcomes, and to adapt to climate change and/or socio-economic development. Scenario-based decision support was considered for almost all research aims. However, optimisation-based decision support was considered for only four research aims, including water quality management (e.g., [17]), groundwater management (e.g., [69]), water supply management (e.g., [80]) and irrigation management (e.g., [8]). In addition, a combined scenario-based and optimisation-based approach was considered frequently for river-related management (e.g., [113]), water supply and demand management (e.g., [18]) and nutrient management (e.g., [6]).

\subsection{Type of Adaptation Options}

A considerable number of these reviewed studies were designed with respect to climate change (e.g., changes in sea level, precipitation and temperature) and/or socio-economic stressors (e.g., 
population growth, changes in industrial and agricultural production). A wide range of management measure types were therefore considered to adapt to changes in climatic and/or non-climatic drivers (Table 1). The category of management measures was considered differently in different research aims. Institutional and social management measures were considered for almost all research aims. Technological and engineered measures were considered most frequently for management of water supply (e.g., $[78,87])$ and irrigation (e.g., $[8,93])$ while ecosystem-based measures were considered most frequently for management of river-related issues (e.g., [105,110]), water quality (e.g., [26,45]) and nutrients (e.g., $[6,7])$.

\subsection{Use of Quantitative and Qualitative Data}

Almost half of the reviewed studies (47\%) applied both quantitative and qualitative data to construct DAGs and populate CPTs in their BNs (Figure 2a). Quantitative data was used by only 58 reviewed studies $(44 \%)$, whereas very few studies $(9 \%)$ developed networks using only qualitative information (Figure 2a).
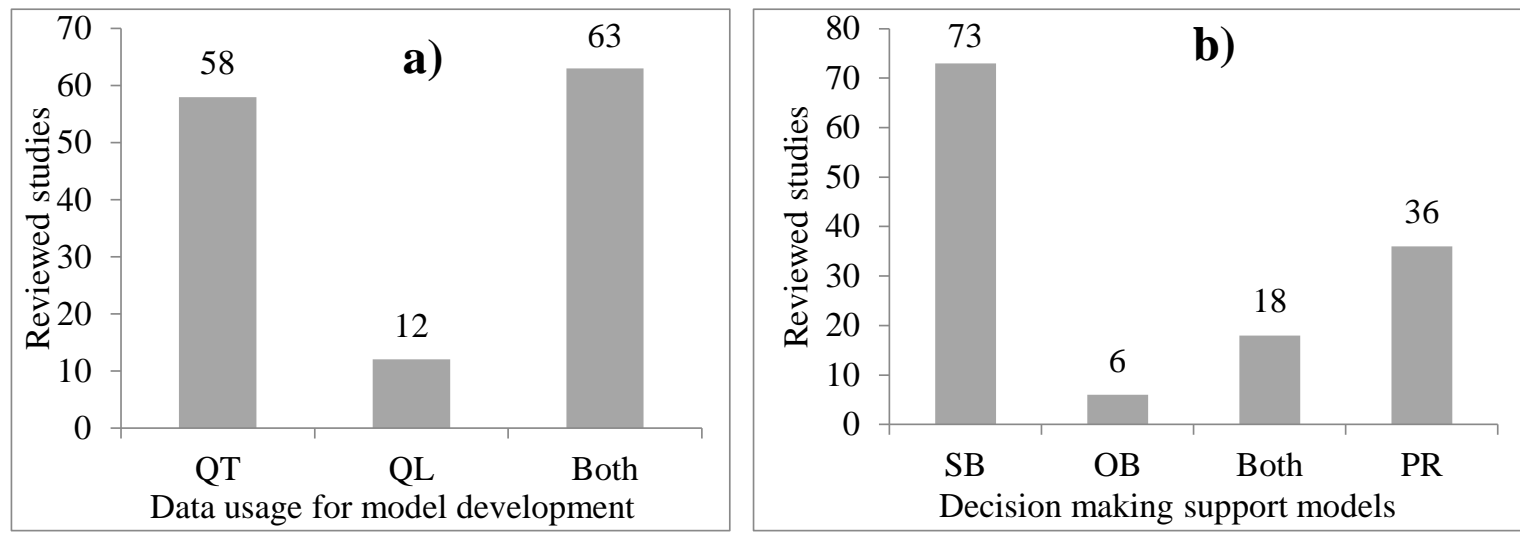

Figure 2. Usage of different types of data in BN construction (a) and usage of BNs for different types of decision support (b) in water resource management. QT: Quantitative data, QL: Qualitative data, Both: Both quantitative data and qualitative data, SB: Scenario-based approaches, OB: Optimization-based approaches, Both: Both scenario and optimization-based approaches, PR: Predictive only.

A chi-squared test of independence indicated that there was no significant difference in the use of quantitative and/or qualitative data across BNs used for optimization-based versus scenario-based decision support $(p=0.544)$. Neither was there any significant difference in the use of quantitative data and/or qualitative data in BNs used to evaluate the performance on the different categories of management measure $(p=0.249)$.

\subsection{Decision Making Support Approaches and Evaluation of Management Options of the Reviewed Studies}

The general value of BNs as decision support tools is evidenced by their widespread use in water resource management, with more than $72 \%$ of the reviewed studies reporting that their BNs were developed to support decision-making processes. About a quarter of the reviewed articles $(n=36)$, described BNs, which were developed for predictive modelling only (Figure $2 b$ ). The scenario-based approaches were most commonly used to evaluate the effectiveness of management options under different scenarios, accounting for $68 \%$ of the reviewed applications (Figure 2b). Optimization-based approaches were encountered much less frequently, only appearing in $18 \%$ of the reviewed applications. Only seven (e.g., $[1,45,106])$ of these optimization-based studies actually incorporated decision nodes, cost node(s) and utility node(s) into their BNs to optimize selection of water-related management options. Other studies (e.g., $[17,18])$ coupled BNs with external economic valuations to optimize the selection of water management measures. 
A total of 76 reviewed studies (57\%) evaluated the performance of management options for water resource systems. More than $61 \%$ of these seventy-six studies evaluated the performance of institutional and social management measure (ISM), while $47 \%$ considered technological and engineered measures and $37 \%$ evaluated ecosystem-based measures (Figure 3). More than 36\% of these seventy-six reviewed applications considered management measures from more than one management category. For example, eight studies (11\%) evaluated the performance of all three categories of management measure (ISM, TEM and EM), and nineteen studies (25\%) in total evaluated two categories of measures for water resource management (Figure 3).

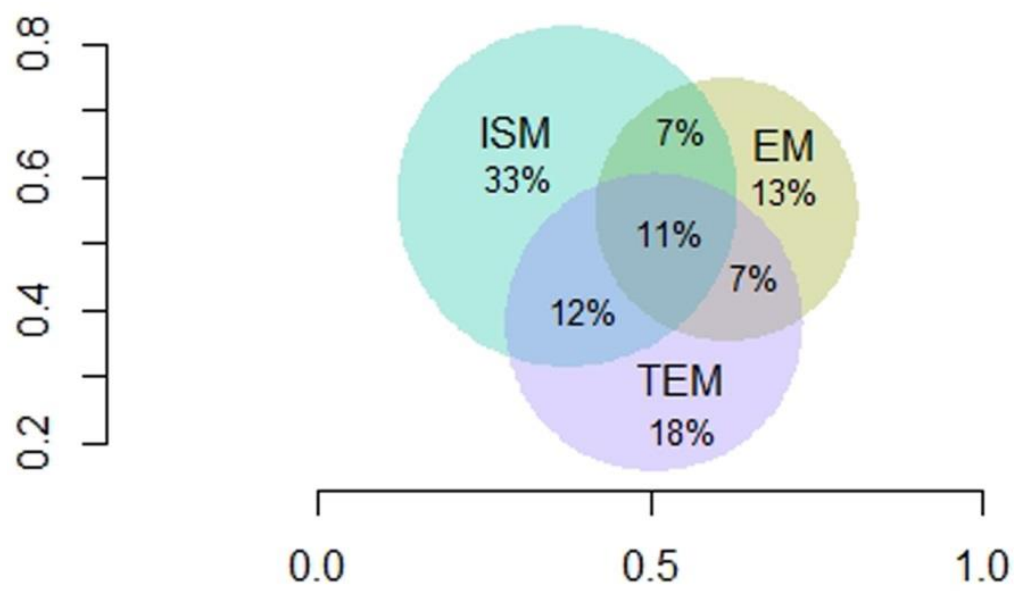

Figure 3. Evaluation of different categories of management measures in the reviewed studies. ISM: Institutional and social measures, TEM: Technological and engineered measures, EM: Ecosystem-based measures.

Scenario-based approaches were used frequently to evaluate every category, and category combination, of management measures (Figure 4). In contrast, optimization-based approaches were applied significantly less frequently to evaluate the performance of institutional and social measures. A chi-squared test of independence indicated that there was significant dependence $(p=0.076)$ between the types of management measure(s) being evaluated and the decision support approach used for that evaluation (optimization-based model versus scenario-based models versus combined optimization and scenario-based models).

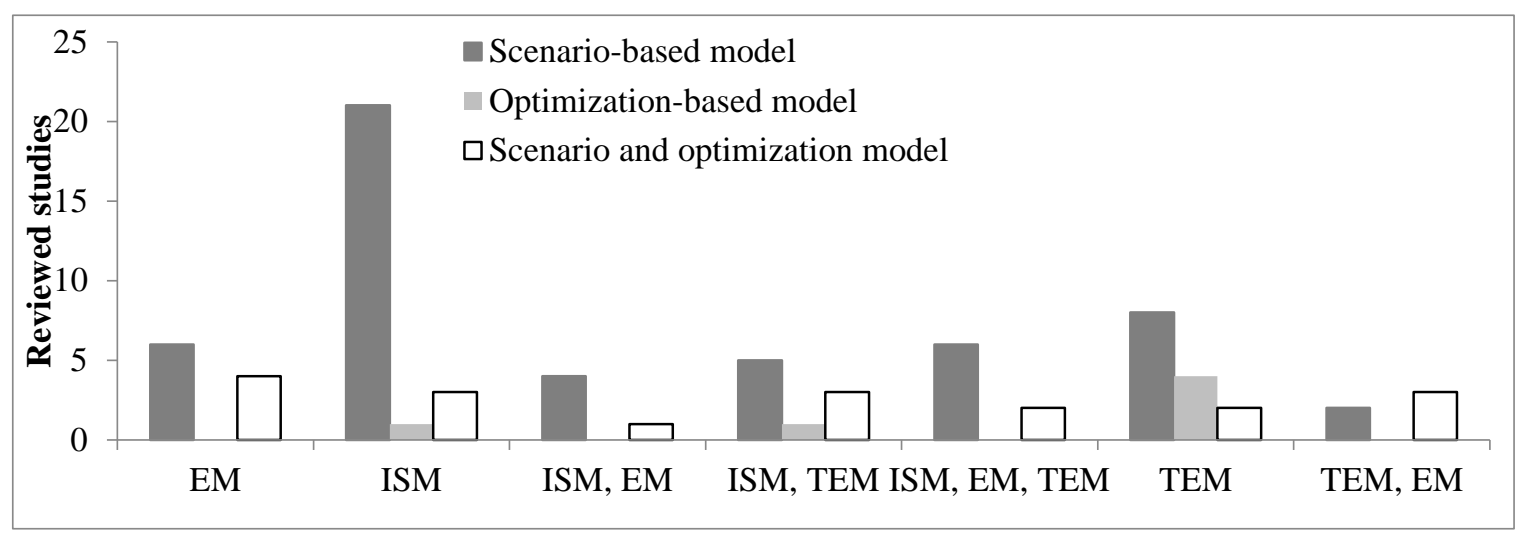

Figure 4. Application of optimization and scenario-based approaches to evaluate different categories of management measures. ISM: Institutional and social measures, TEM: Technological and engineered measures, EM: Ecosystem-based measures.

\subsection{Discussion and Recommendations}

This systematic quantitative literature review has found that a considerable number of studies have applied BNs as a decision support tool to evaluate the performance of management options to inform 
decision-making for complex and uncertain systems, in relation to a wide variety of water-related issues. In particular, water quality management, water supply management, groundwater management and irrigation management are the major concerns on which the majority of $\mathrm{BN}$ applications have been focused on, to date. A high proportion of these studies have sought to understand climatic and/or non-climatic drivers and their impacts on water-related systems and to evaluate the performance of management options under these changing conditions. Effects of numerous climatic drivers have been considered, including sea-level rise on water supply management (e.g., [2]), and on water quality management (e.g., [49]); precipitation and temperature on groundwater management (e.g., [63,64,67]), on reservoir management (e.g., [135]), on water supply management (e.g., [3,132]), on water quality management (e.g., $[27,43,45]$ and on nutrient management (e.g., $[119,126])$ and precipitation on water supply and demand management (e.g., $[18,127,130,131])$. Similarly, the non-climatic drivers that have been considered, have included effects of population growth on water supply and demand management (e.g., [128]), and on water quality management (e.g., [41]); crop production changes in irrigation system management (e.g., $[96,102])$; population growth and agricultural production on water supply and demand management (e.g., [128]); agricultural production on irrigation water management (e.g., [93-95,100]), on water supply management (e.g., [85]), and on groundwater management (e.g., [67]); changes in domestic use and in agricultural and industrial production on water supplies and demand management (e.g., [127]).

Most BN applications identified in this review were found to use both quantitative and qualitative data for the model setup, parameterization and/or calibration. Different types of quantitative and qualitative data were collected in relation to the research aims and data availability of the reviewed studies. Empirical data and model simulations were the two main sources of quantitative data used to construct and calibrate BN applications. Empirical data include water quality samples (e.g., [58]), riparian vegetation and ecological measures (e.g., [106]), dam operation data and population (e.g., [128]), irrigated areas (e.g., [18]) and Geographic Information System (GIS) data (e.g., [81]). Model simulation data from different types of models included a system dynamics model (e.g., [16]), a two-dimensional habitat simulation model (e.g., [115]) and a groundwater flow model (e.g., [59]). Qualitative data (e.g., expert knowledge and stakeholder opinion) are frequently used to calibrate and validate the BNs where empirical data are lacking $[15,21]$. For example, expert knowledge was used to identify the environmental factors (e.g., land use, rainfall, storage level, agricultural areas) affecting the three key water quality parameters (turbidity, colour and crypto) in the reservoirs of New South Wales, Australia, and then quantify the relationships between environmental factors and these water quality variables through populating the CPTs for the model [47]. In addition, meetings with stakeholders, water managers, water experts and researchers were organized to determine the influential variables (e.g., water for people and animals, industrial water demand, groundwater exaction) and their relationships on a water supply and demand system, and then elicit the CPTs based on average values from all participants for the system in Qira Oasis area, Northwest China [3]. The ability of BNs to combine these different types of data is particularly useful for informing decisions under high levels of uncertainty, where the state of a variable or decision outcome is uncertain. This is because BNs are well suited to facilitate stakeholder involvement to identify potential intervention options and incorporate stakeholder expertise to assess the likely consequences of each option even where detailed quantitative data on outcomes is incomplete [1].

Bayesian networks have been widely used in the management of environmental systems with many motives, such as understanding the systems, predicting the current and future changes of the systems under different scenarios, evaluating the performance of management measures, conducting trade-off analysis for selecting an optimal management measure, and informing and supporting decision making with or without participatory process [143]. This systematic quantitative literature review quantified the reviewed studies, applied decision support approaches in the management of complex and uncertain systems, and found that most of these reviewed studies applied scenario-based approaches to help decision-makers or modellers understand water-related systems, and answer the 
question 'what if?', through evaluating the effectiveness of management measures under exploring different scenarios (e.g., [51,127]). Optimization-based approaches were also applied but less frequently. The output of optimization-based approaches was designed to help decision-makers or modellers understand water-related systems and answer the question 'what is best?', through conducting trade-off analysis to find out the most optimal management options with/without exploring different scenarios (e.g., $[17,137])$. Only $27 \%$ of reviewed studies developed BNs for predictive modelling only, meaning that these studies just focused on understanding the systems without exploring any scenarios or management measures (e.g., [36,60,141]).

A major finding from this review is that there was no significant difference in the use of quantitative and/or qualitative data for both developing decision-making support models and evaluating different management measures. However, a significant dependence was found between the types of management measures being assessed and the decision support approaches used to evaluate the performance of those measures. This may be driven by implementation constraints, especially given the challenges inherent in quantifying the costs and benefits of institutional and social measures sufficiently for inclusion in the optimization-based approaches. It is also inherent that the nature of cost and utility functions will probably influence the decision of selecting optimal management measures derived from the optimization-based approaches, and thus, values of cost and utility should also be estimated as accurately as possible [106]. Another potential challenge of the optimization-based approaches is their performance assessments. Barton et al. [6] indicated that the modellers faced a particular challenge to validate the performance of optimisation-based approaches because they include cost and utility functions. In addition, sensitivity analysis is not able to be conducted to identify the influential levels between factors and targeted variables in the optimization-based approaches. Thus, these challenges may explain why cost-benefit and cost-effectiveness optimization approaches are only rarely applied to evaluate the performance of these types of measures.

A wide range of adaptation options, encompassing engineered and technological measures, institutional and social measures, and ecosystem-based measures can be incorporated into BNs to help decision-makers evaluate the effectiveness of these measures for water resource management. Potential outcomes from these measures can be described using qualitative and/or quantitative data. BNs have the capacity to help decision-makers consider multiple and potential interactions and interventions among adaptation options in water resource systems under climate change and socio-economic stressors. Institutional and social measures were found to be the most frequently assessed category of management measure. This may be because this category includes a wide range of measures, such as water pricing (e.g., [18,64,102,130]), compensation payments (e.g., [69]), discharge permits (e.g., [3,28]), educational programs (e.g., [2,67]) and improvements in management practices (e.g., $[29,65,100,137])$.

This review found that the performance of institutional and social management measures was more often evaluated by scenario-based approaches than by optimization-based approaches, whilst, the performance of technological and engineered measures was mainly evaluated by optimization-based approaches. It is likely to be much more straightforward to estimate implementation costs for engineered and technical measures, such as the construction of reservoirs (e.g., [3,29,31,134]), desalination plants (e.g., [70,79,89]), rainwater tanks (e.g., [2,88]) and improvements in irrigation technology (e.g., [102]), than to estimate the societal costs arising from institutional and social measures, such as modifications to property rights, community education programs or increasing household water prices. Depending on the system and adaptation measures being considered, the societal benefits delivered by institutional and social adaptation measures could be estimated by methods such as author expertise (e.g., [21,106]), market valuations and literature reviews (e.g., [8,16]), non-market valuation (e.g., [6]) and interviews with local experts (e.g., [137]).

Another important finding is that a combination of scenario-based and optimization-based approach was more often applied to evaluate ecosystem-based management measures, such as riparian planting and restoration options (e.g., [7,45,53]) or increasing forest cover (e.g., [26,94]). The use of optimization-based approaches to assess the performance of ecosystem-based measures has been 
suggested, but it is possible that the inclusion of ecosystem-based measures in BNs may be inhibited by a lack of comparable standards and methodologies for assessing their effectiveness [4]. Therefore, both scenario-based and optimization-based approaches were applied to evaluate the performance of ecosystem-based measures under different potential scenarios as a way of identifying robust management options. The successful evaluation of ecosystem-based management methods again illustrates the usefulness of the ability for a $\mathrm{BN}$ to incorporate expert opinion to bridge knowledge gaps where precise data are lacking [15].

Institutional and social measures might be capable of providing highly cost-effective or cost-efficient solutions, but results from the review suggest that they are less likely to be evaluated in optimization-based decision support. We propose two potential solutions to this dilemma. Firstly, interdisciplinary collaborations are to be encouraged because they can combine engineering and technical expertise to determine potential outcomes from institutional and social measures with economics and social science expertise, to quantify the societal costs and benefits of implementing measures as diverse as reallocating property rights or increasing household water prices. Secondly, multi-criteria decision analysis (MCDA) should be considered as a possible optimization approach because of its ability to answer 'which is best?' questions, where data for the cost of implementation is lacking. When using MCDA, it is typically sufficient to know that all proposed management options are deemed feasible and acceptable from societal and technical perspectives, by the group of stakeholders involved in BN construction and decision support. A 'which is best?' analysis can then be conducted based on multiple outcomes, weighted appropriately by agreed preference weightings from decision-makers. BNs could contribute very effectively to MCDA, in which the heuristic possibilities of BNs could be extremely useful. An approach combining MCDA and BNs could enable these to complement each other to support the decision-making process further. For example, in a system safety assessment, Fenton and Neil [144] applied BNs to compute values for each criterion with uncertainty for a given action, and then MCDA was applied to combine the values and rank the actions. The authors indicated that BNs might not provide a complete solution for the safety assessment system with multiple criteria (e.g., economic, environmental and political criteria) and, in this case, MCDA is needed to weight these criteria to make an appropriate decision on the nature of deployment. In addition, Khakzad and Reniers [145] applied both BNs and MCDA in the risk-based design of chemical plants. More specifically, BNs were employed to estimate both on-site and off-site risks posed by potential major accidents in chemical plants. The results of BNs were used as input data in MCDA to find an optimal layout for chemical plants. The authors stated that BNs facilitated the incorporation of complicated interdependencies and conditional probabilities encountered in accident analysis and risk assessment, and that MCDA allowed considering incommensurate and conflicting decision parameters, inevitable in most decision analyses.

Although BNs have considerable potential for decision-making support in water resource management under climate change and socioeconomic stressors, they also have some limitations in their development and calibration $[6,13,103]$. In this review, two main limitations were discussed based on evidence from the reviewed studies. The first potential limitation in these types of applications is knowledge bias in expert elicitation for both scenarios and management interventions. Although experts can have considerable knowledge of water resource systems, the challenges inherent in integrating this knowledge into complex water system models may affect model outcomes [13]. In addition, time commitment and dominant personalities are potential challenges to the process of constructing BNs using expert-derived data [146]. For example, a study by McVittie et al. [21] used qualitative data alone to assess and value the delivery of ecosystem services from riparian buffer strips. The authors voiced concern that although BNs are a promising participatory decision support tool, trade-offs between realism, precision and the benefits of stakeholder involvement in the decision-making process have to be considered carefully before embarking on their use. Chen and Pollino [143] also stated that BNs can be built entirely from expert elicitation or data learning; 
however, models may be more meaningful and valuable when expert elicited prior probabilities, and then empirical data, updated the models.

Another challenge for the application of BNs as decision support tools for water resource management concerns their quantitative calibration and validation. Empirical data (e.g., field observations) or independent assessments are needed to increase confidence in the ability of BNs to identify appropriate management strategies [6,15]. For example, Death et al. [7] collected invertebrate communities and GIS data from Manawatu River, New Zealand, to develop BNs for an invertebrate-based measure of ecological conditions under different management scenarios. The authors indicate that using empirical data for calibration and validation of BNs could enhance model performance, and lead to more confident decision making. In addition, Hamilton et al. [54] used water quality monitoring data, simulation models and expert opinion to develop BNs for exploring the major factors influencing algal blooms in Deception Bay, Queensland, Australia. The authors suggest that the use of observation data for calibrating BNs may lead to more robust results. Thus, to promote the performance of $\mathrm{BNs}$ for water resource management, decision-making will require a greater emphasis on the use of empirical data to construct and refine models, and/or to validate expert opinions.

Although BNs have been applied widely in these settings, several recommendations can be made on the basis of this review for future research priorities and challenges, which should be considered to further develop BNs as decision support tools for managing water resource systems under climate change and socio-economic stressors:

(1) Where possible, empirical data should be used to construct and validate BNs to increase model performance and assist in identifying robust adaptation options.

(2) Model parameterization and the estimation of the costs and benefits of all the different categories of management options in BNs for decision support should be based on interdisciplinary collaborations and a range of different sources, including expert opinions, market and non-market valuations and modelling results.

(3) Ecosystem-based measures have been applied less frequently in BN decision support models, but these types of measure could offer win-win solutions for both water resource management and ecosystem service delivery.

(4) Bayesian networks could be configured to deliver multi-criteria decision analysis to facilitate 'which is best?' decision support, where cost data for particular management option types are not available.

Author Contributions: T.D.P. conceived the idea for the study, constructed systematic literature review database, searched and read reviewed articles and prepared the manuscript. J.C.R.S. and B.S.-K. provided a great support in data analysis and revisions of the manuscript. S.J.C. provided critical revisions to improve the manuscript. O.S. and W.L.H. provided useful suggestions and revisions to improve the manuscript. L.T.D. and I.T. provided support in reading reviewed articles and revisions of the manuscript.

Funding: This study received no external funding.

Conflicts of Interest: The authors declared no conflict of interest.

\section{References}

1. Rivers-Moore, N.A. Exploratory use of a Bayesian network process for translating stakeholder perceptions of water quality problems in a catchment in South Africa. Water SA 2016, 42, 306-315. [CrossRef]

2. Noi, L.V.T.; Nitivattananon, V. Assessment of vulnerabilities to climate change for urban water and wastewater infrastructure management: Case study in Dong Nai river basin, Vietnam. Environ. Dev. 2015, 16, 119-137. [CrossRef]

3. Xue, J.; Gui, D.; Lei, J.; Zeng, F.; Mao, D.; Zhang, Z. Model development of a participatory Bayesian network for coupling ecosystem services into integrated water resources management. J. Hydrol. 2017, 554, 50-65. [CrossRef] 
4. Noble, I.R.; Huq, S.; Anokhin, Y.A.; Carmin, J.; Goudou, D.; Lansigan, F.P.; Osman-Elasha, B.; Villamizar, A. Adaptation Needs and Options. In Climate Change 2014: Impacts, Adaptation, and Vulnerability. Part A: Global and Sectoral Aspects. Contribution of Working Group II to the Fifth Assessment Report of the Intergovernmental Panel on Climate Change; Field, C.B., Barros, V.R., Dokken, D.J., Mach, K.J., Mastrandrea, M.D., Bilir, T.E., Chatterjee, M., Ebi, K.L., Estrada, Y.O., Genova, R.C., et al., Eds.; Cambridge University Press: Cambridge, UK; New York, NY, USA, 2014; pp. 833-868.

5. De Bruin, K.; Goosen, H.; van Ierland, C.; Groeneveld, A. Costs and benefits of adapting spatial planning to climate change: Lessons learned from a large-scale urban development project in the Netherlands. Reg. Environ. Chang. 2014, 14, 1009-1020. [CrossRef]

6. Barton, D.N.; Saloranta, T.; Moe, S.J.; Eggestad, H.O.; Kuikka, S. Bayesian belief networks as a meta-modelling tool in integrated river basin management-Pros and cons in evaluating nutrient abatement decisions under uncertainty in a Norwegian river basin. Ecol. Econ. 2008, 66, 91-104. [CrossRef]

7. Death, R.G.; Death, F.; Stubbington, R.; Joy, M.K.; van den Belt, M. How good are Bayesian belief networks for environmental management? A test with data from an agricultural river catchment. Freshw. Biol. 2015, 60, 2297-2309.

8. Batchelor, C.; Cain, J. Application of belief networks to water management studies. Agric. Water Manag. 1999, 40, 5157. [CrossRef]

9. Jensen, F.V.; Nielsen, D.T. Bayesian Networks and Decision Graphs, 2nd ed.; Information Science and Statistics, Jordan, M., Kleinberg, J., Scholkopf, B., Eds.; Springer: New York, NY, USA, 2007.

10. Aguilera, P.A.; Fernández, A.; Fernández, R.; Rumí, R.; Salmerón, A. Bayesian networks in environmental modelling. Environ. Model. Softw. 2011, 26, 1376-1388. [CrossRef]

11. McDonald, K.S.; Ryder, D.S.; Tighe, M. Developing best-practice Bayesian Belief Networks in ecological risk assessments for freshwater and estuarine ecosystems: A quantitative review. J. Environ. Manag. 2015, 154, 190-200. [CrossRef]

12. Sperotto, A.; Molina, J.L.; Torresan, S.; Critto, A.; Marcomini, A. Reviewing Bayesian Networks potentials for climate change impacts assessment and management: A multi-risk perspective. J. Environ. Manag. 2017, 202 Pt 1, 320-331. [CrossRef]

13. Phan, T.D.; Smart, J.C.R.; Capon, S.J.; Hadwen, W.L.; Sahin, O. Applications of Bayesian belief networks in water resource management: A systematic review. Environ. Model. Softw. 2016, 85, 98-111. [CrossRef]

14. Pollino, C.A.; Woodberry, O.; Nicholson, A.; Korb, K.; Hart, B.T. Parameterisation and evaluation of a Bayesian network for use in an ecological risk assessment. Environ. Model. Softw. 2007, 22, 1140-1152. [CrossRef]

15. Kelly, R.A.; Jakeman, A.J.; Barreteau, O.; Borsuk, M.E.; ElSawah, S.; Hamilton, S.H.; Henriksen, H.J.; Kuikka, S.; Maier, H.R.; Rizzoli, A.E.; et al. Selecting among five common modelling approaches for integrated environmental assessment and management. Environ. Model. Softw. 2013, 47, 159-181. [CrossRef]

16. Ames, D.P.; Neilson, B.T.; Stevens, D.K.; Lall, U. Using Bayesian networks to model watershed management decisions: An East Canyon Creek case study. J. Hydroinform. 2005, 7, 267-282. [CrossRef]

17. Mesbah, S.M.; Kerachian, R.; Nikoo, M.R. Developing real time operating rules for trading discharge permits in rivers: Application of Bayesian Networks. Environ. Model. Softw. 2009, 24, 238-246. [CrossRef]

18. Portoghese, I.; D’Agostino, D.; Giordano, R.; Scardigno, A.; Apollonio, C.; Vurro, M. An integrated modelling tool to evaluate the acceptability of irrigation constraint measures for groundwater protection. Environ. Model. Softw. 2013, 46, 90-103. [CrossRef]

19. Bromley, J.; Jackson, N.A.; Clymer, O.J.; Giacomello, A.M.; Jensen, F.V. The use of Hugin ${ }^{\circledR}$ to develop Bayesian networks as an aid to integrated water resource planning. Environ. Model. Softw. 2005, 20, $231-242$. [CrossRef]

20. Ticehurst, J.L.; Letcher, R.A.; Rissik, D. Integration modelling and decision support: A case study of the Coastal Lake Assessment and Management (CLAM) Tool. Math. Comput. Simul. 2008, 78, 435-449. [CrossRef]

21. McVittie, A.; Norton, L.; Martin-Ortega, J.; Siameti, I.; Glenk, K.; Aalders, I. Operationalizing an ecosystem services-based approach using Bayesian Belief Networks: An application to riparian buffer strips. Ecol. Econ. 2015, 110, 15-27. [CrossRef]

22. Joseph, S.A.; Adams, B.J.; McCabe, B. Methodology for Bayesian Belief Network Development to Facilitate Compliance with Water Quality Regulations. J. Infrastruct. Syst. 2010, 16, 58-65. [CrossRef] 
23. Tang, C.; Yi, Y.; Yang, Z.; Sun, J. Risk analysis of emergent water pollution accidents based on a Bayesian Network. J. Environ. Manag. 2016, 165, 199-205. [CrossRef] [PubMed]

24. Cheng, T.; Wang, P.; Lu, Q. Risk scenario prediction for sudden water pollution accidents based on Bayesian networks. Int. J. Syst. Assur. Eng. Manag. 2018, 9, 1165-1177. [CrossRef]

25. Lee, B.; Kullman, S.W.; Yost, E.E.; Meyer, M.T.; Worley-Davis, L.; Williams, C.M.; Reckhow, K.H. Predicting characteristics of rainfall driven estrogen runoff and transport from swine AFO spray fields. Sci. Total Environ. 2015, 532, 571-580. [CrossRef] [PubMed]

26. Moe, S.J.; Haande, S.; Couture, R.M. Climate change, cyanobacteria blooms and ecological status of lakes: A Bayesian network approach. Ecol. Model. 2016, 337, 330-347. [CrossRef]

27. Sadoddin, A.; Letcher, R.A.; Jakeman, A.J.; Newham, L.T.H. A Bayesian decision network approach for assessing the ecological impacts of salinity management. Math. Comput. Simul. 2005, 69, 162-176. [CrossRef]

28. Nikoo, M.R.; Kerachian, R.; Niksokhan, M.H. Equitable Waste Load Allocation in Rivers Using Fuzzy Bi-matrix Games. Water Resour. Manag. 2012, 26, 4539-4552. [CrossRef]

29. Forio, M.A.E.; Landuyt, D.; Bennetsen, E.; Lock, K.; Nguyen, T.H.T.; Ambarita, M.N.D.; Musonge, P.L.S.; Boets, P.; Everaert, G.; Dominguez-Granda, L.; et al. Bayesian belief network models to analyse and predict ecological water quality in rivers. Ecol. Model. 2015, 312, 222-238. [CrossRef]

30. Hines, E.E.; Landis, W.G. Regional risk assessment of the Puyallup River Watershed and the evaluation of low impact development in meeting management goals. Integr. Environ. Assess. Manag. 2014, 10, 269-278. [CrossRef]

31. Said, A. The Implementation of a Bayesian Network for Watershed Management Decisions. Water Resour. Manag. 2006, 20, 591-605. [CrossRef]

32. Ha, H.; Stenstrom, M.K. Identification of land use with water quality data in stormwater using a neural network. Water Res. 2003, 37, 4222-4230. [CrossRef]

33. Murray, S.; Ghazali, M.; McBean, E.A. Real-Time Water Quality Monitoring: Assessment of Multisensor Data Using Bayesian Belief Networks. J. Water Resour. Plan. Manag. 2012, 138, 63-70. [CrossRef]

34. Nikoo, M.R.; Kerachian, R.; Malakpour-Estalaki, S.; Bashi-Azghadi, S.N.; Azimi-Ghadikolaee, M.M. A probabilistic water quality index for river water quality assessment: A case study. Environ. Monit. Assess. 2011, 181, 465-478. [CrossRef] [PubMed]

35. Park, M.-H.; Stenstrom, M.K. Using satellite imagery for stormwater pollution management with Bayesian networks. Water Res. 2006, 40, 3429-3438. [CrossRef] [PubMed]

36. Wang, G.; Wang, S.; Kang, Q.; Duan, H.; Wang, X. An integrated model for simulating and diagnosing the water quality based on the system dynamics and Bayesian network. Water Sci. Technol. 2016, 74, 2639-2655. [CrossRef] [PubMed]

37. Liu, J.; Liu, R.; Zhang, L.; Zhang, Z.; Cai, Y. A Bayesian Network-based risk dynamic simulation model for accidental water pollution discharge of mine tailings ponds at watershed-scale. J. Environ. Manag. 2019, 246, 821-831. [CrossRef] [PubMed]

38. Mayfield, H.J.; Bertone, E.; Smith, C.; Sahin, O. Use of a structure aware discretisation algorithm for Bayesian networks applied to water quality predictions. Math. Comput. Simul. 2019. [CrossRef]

39. Wijesiri, B.; Deilami, K.; Goonetilleke, A. Evaluating the relationship between temporal changes in land use and resulting water quality. Environ. Pollut. 2018, 234, 480-486. [CrossRef]

40. Dyer, F.; ElSawah, S.; Croke, B.; Griffiths, R.; Harrison, E.; Lucena-Moya, P.; Jakeman, A. The effects of climate change on ecologically-relevant flow regime and water quality attributes. Stoch. Environ. Res. Risk Assess. 2014, 28, 67-82. [CrossRef]

41. Liyanage, C.P.; Yamada, K. Impact of population growth on the water quality of natural water bodies. Sustainability 2017, 9, 1405. [CrossRef]

42. McLaughlin, D.B.; Reckhow, K.H. A Bayesian network assessment of macroinvertebrate responses to nutrients and other factors in streams of the Eastern Corn Belt Plains, Ohio, USA. Ecol. Model. 2017, 345, 21-29. [CrossRef]

43. Nojavan, F.A.; Qian, S.S.; Paerl, H.W.; Reckhow, K.H.; Albright, E.A. A study of anthropogenic and climatic disturbance of the New River Estuary using a Bayesian belief network. Mar. Pollut. Bull. 2014, 83, 107-115. [CrossRef] [PubMed] 
44. Ramin, M.; Stremilov, S.; Labencki, T.; Gudimov, A.; Boyd, D.; Arhonditsis, G.B. Integration of numerical modeling and Bayesian analysis for setting water quality criteria in Hamilton Harbour, Ontario, Canada. Environ. Model. Softw. 2011, 26, 337-353. [CrossRef]

45. Keshtkar, A.R.; Salajegheh, A.; Sadoddin, A.; Allan, M.G. Application of Bayesian networks for sustainability assessment in catchment modeling and management (Case study: The Hablehrood river catchment). Ecol. Model. 2013, 268, 48-54. [CrossRef]

46. Lynam, T.; Drewry, J.; Higham, W.; Mitchell, C. Adaptive modelling for adaptive water quality management in the Great Barrier Reef region, Australia. Environ. Model. Softw. 2010, 25, 1291-1301. [CrossRef]

47. Bertone, E.; Sahin, O.; Richards, R.; Roiko, A. Extreme events, water quality and health: A participatory Bayesian risk assessment tool for managers of reservoirs. J. Clean. Prod. 2016, 135, 657-667. [CrossRef]

48. Dorner, S.; Shi, J.; Swayne, D. Multi-objective modelling and decision support using a Bayesian network approximation to a non-point source pollution model. Environ. Model. Softw. 2007, 22, 211-222. [CrossRef]

49. Ticehurst, J.L.; Newham, L.T.H.; Rissik, D.; Letcher, R.A.; Jakeman, A.J. A Bayesian network approach for assessing the sustainability of coastal lakes in New South Wales, Australia. Environ. Model. Softw. 2007, 22, 1129-1139. [CrossRef]

50. Reckhow, K.H. Water quality prediction and probability network models. Can. J. Fish. Aquat. Sci. 1999, 56, 1150. [CrossRef]

51. Carpani, M.; Giupponi, C. Construction of a bayesian network for the assessment of agri-environmental measures-The case study of the venice lagoon watershed. Ital. J. Agron. 2010, 5, 265-274. [CrossRef]

52. Holzkaemper, A.; Kumar, V.; Surridge, B.W.J.; Paetzold, A.; Lerner, D.N. Bringing diverse knowledge sources together-A meta-model for supporting integrated catchment management. J. Environ. Manag. 2012, 96, 116-127. [CrossRef]

53. Kragt, M.E.; Newham, L.T.H.; Bennett, J.; Jakeman, A.J. An integrated approach to linking economic valuation and catchment modelling. Environ. Model. Softw. 2011, 26, 92-102. [CrossRef]

54. Hamilton, G.S.; Fielding, F.; Chiffings, A.W.; Hart, B.T.; Johnstone, R.W.; Mengersen, K. Investigating the use of a Bayesian Network to Model the Risk of Lyngbya majuscula Bloom Initiation in Deception Bay, Queensland, Australia. Hum. Ecol. Risk Assess. 2007, 13, 1271-1287. [CrossRef]

55. Pike, W.A. Modeling drinking water quality violations with Bayesian networks. J. Am. Water Resour. Assoc. 2004, 40, 1563-1578. [CrossRef]

56. Giordano, R.; D'Agostino, D.; Apollonio, C.; Lamaddalena, N.; Vurro, M. Bayesian Belief Network to support conflict analysis for groundwater protection: The case of the Apulia region. J. Environ. Manag. 2013, 115, 136-146. [CrossRef] [PubMed]

57. Roozbahani, A.; Ebrahimi, E.; Banihabib, M.E. A Framework for Ground Water Management Based on Bayesian Network and MCDM Techniques. Water Resour. Manag. 2018, 32, 4985-5005. [CrossRef]

58. Aguilera, P.A.; Fernandez, A.; Ropero, R.F.; Molina, L. Groundwater quality assessment using data clustering based on hybrid Bayesian networks. Stoch. Environ. Res. Risk Assess. 2013, 27, 435-447. [CrossRef]

59. Fienen, M.N.; Masterson, J.P.; Plant, N.G.; Gutierrez, B.T.; Thieler, E.R. Bridging groundwater models and decision support with a Bayesian network. Water Resour. Res. 2013, 49, 6459-6473. [CrossRef]

60. Nolan, B.T.; Fienen, M.N.; Lorenz, D.L. A statistical learning framework for groundwater nitrate models of the Central Valley, California, USA. J. Hydrol. 2015, 531, 902-911. [CrossRef]

61. Shihab, K. Dynamic modeling of groundwater pollutants with Bayesian networks. Appl. Artif. Intell. 2008, 22, 352-376. [CrossRef]

62. Moghaddam, H.K.; Moghaddam, H.K.; Kivi, Z.R.; Bahreinimotlagh, M.; Alizadeh, M.J. Developing comparative mathematic models, BN and ANN for forecasting of groundwater levels. Groundw. Sustain. Dev. 2019, 9, 100237. [CrossRef]

63. Carmona, G.; Molina, J.L.; Bromley, J.; Varela-Ortega, C.; Garcia-Arostegui, J.L. Object-Oriented Bayesian Networks for Participatory Water Management: Two Case Studies in Spain. J. Water Resour. Plan. Manag. 2011, 137, 366-376. [CrossRef]

64. Carmona, G.; Varela-Ortega, C.; Bromley, J. Participatory modelling to support decision making in water management under uncertainty: Two comparative case studies in the Guadiana river basin, Spain. J. Environ. Manag. 2013, 128, 400-412. [CrossRef] [PubMed] 
65. Henriksen, H.J.; Rasmussen, P.; Brandt, G.; von Bülow, D.; Jensen, F.V. Public participation modelling using Bayesian networks in management of groundwater contamination. Environ. Model. Softw. 2007, 22, 1101-1113. [CrossRef]

66. Olalla, F.M.D.; Dominguez, A.; Ortega, F.; Artigao, A.; Fabeiro, C. Bayesian networks in planning a large aquifer in Eastern Mancha, Spain. Environ. Model. Softw. 2007, 22, 1089-1100. [CrossRef]

67. Subagadis, Y.H.; Grundmann, J.; Schütze, N.; Schmitz, G.H. An integrated approach to conceptualise hydrological and socio-economic interaction for supporting management decisions of coupled groundwater-agricultural systems. Environ. Earth Sci. 2014, 72, 4917-4933. [CrossRef]

68. Mohajerani, H.; Kholghi, M.; Mosaedi, A.; Farmani, R.; Sadoddin, A.; Casper, M. Application of Bayesian Decision Networks for Groundwater Resources Management Under the Conditions of High Uncertainty and Data Scarcity. Water Resour. Manag. 2017, 31, 1859-1879. [CrossRef]

69. Farmani, R.; Henriksen, H.J.; Savic, D. An evolutionary Bayesian belief network methodology for optimum management of groundwater contamination. Environ. Model. Softw. 2009, 24, 303-310. [CrossRef]

70. Molina, J.L.; Farmani, R.; Bromley, J. Aquifers Management through Evolutionary Bayesian Networks: The Altiplano Case Study (SE Spain). Water Resour. Manag. 2011, 25, 3883-3909. [CrossRef]

71. Ghabayen, S.M.S.; McKee, M.; Kemblowski, M. Ionic and isotopic ratios for identification of salinity sources and missing data in the Gaza aquifer. J. Hydrol. 2006, 318, 360-373. [CrossRef]

72. de Santa Olalla, F.J.M.; Domínguez, A.; Artigao, A.; Fabeiro, C.; Ortega, J.F. Integrated water resources management of the Hydrogeological Unit “Eastern Mancha” using Bayesian Belief Networks. Agric. Water Manag. 2005, 77, 21-36. [CrossRef]

73. Henriksen, H.J.; Zorrilla-Miras, P.; de la Hera, A.; Brugnach, M. Use of Bayesian belief networks for dealing with ambiguity in integrated groundwater management. Integr. Environ. Assess. Manag. 2012, 8, 430-444. [CrossRef] [PubMed]

74. Martinez-Santos, P.; Henriksen, H.J.; Zorrilla, R.; Martinez-Alfaro, P.E. Comparative reflections on the use of modelling tools in conflictive water management settings: The Mancha Occidental aquifer, Spain. Environ. Model. Softw. 2010, 25, 1439-1449. [CrossRef]

75. Chan, T.; Ross, H.; Hoverman, S.; Powell, B. Participatory development of a Bayesian network model for catchment-based water resource management. Water Resour. Res. 2010, 46. [CrossRef]

76. Pang, A.P.; Sun, T. Bayesian networks for environmental flow decision-making and an application in the Yellow River estuary, China. Hydrol. Earth Syst. Sci. 2014, 18, 1641-1651. [CrossRef]

77. Avilés, A.; Célleri, R.; Solera, A.; Paredes, J. Probabilistic forecasting of drought events using Markov chainand Bayesian network-based models: A case study of an Andean regulated river basin. Water 2016, 8, 37. [CrossRef]

78. Ahmadi, A.; Karamouz, M.; Moridi, A. Robust Methods for Identifying Optimal Reservoir Operation Strategies Using Deterministic and Stochastic Formulations. Water Resour. Manag. 2010, 24, 2527-2552. [CrossRef]

79. Bullene, R.E.; Brooks, J.P.; Boone, E.L.; Lipchin, C.; Sorrell, T.P.; Stewart, C.R. Uncertainty Quantification for a Middle East Water Supply System. J. Water Resour. Plan. Manag. 2013, 139, 223-234. [CrossRef]

80. Ghabayen, S.; McKee, M.; Kemblowski, M. Characterization of uncertainties in the operation and economics of the proposed seawater desalination plant in the Gaza Strip. Desalination 2004, 161, 191-201. [CrossRef]

81. Francis, R.A.; Guikema, S.D.; Henneman, L. Bayesian Belief Networks for predicting drinking water distribution system pipe breaks. Reliab. Eng. Syst. Saf. 2014, 130,1-11. [CrossRef]

82. Hunter, P.R.; de Sylor, M.A.; Risebro, H.L.; Nichols, G.L.; Kay, D.; Hartemann, P. Quantitative microbial risk assessment of cryptosporidiosis and giardiasis from very small private water supplies. Risk Anal. 2011, 31, 228-236. [CrossRef]

83. Peng, Z.; Zhang, L.; Yin, J.; Wang, H. Study of impact factors of willingness to pay regarding water reserve of South-to-North Water Diversion Project in Beijing based on Bayesian network model. J. Clean. Prod. 2018, 184, 569-578. [CrossRef]

84. Cronk, R.; Bartram, J. Identifying opportunities to improve piped water continuity and water system monitoring in Honduras, Nicaragua, and Panama: Evidence from Bayesian networks and regression analysis. J. Clean. Prod. 2018, 196,1-10. [CrossRef]

85. Dondeynaz, C.; Puga, J.L.; Moreno, C.C. Bayesian networks modelling in support to cross-cutting analysis of water supply and sanitation in developing countries. Hydrol. Earth Syst. Sci. 2013, 17, 3397-3419. [CrossRef] 
86. Fisher, M.B.; Shields, K.F.; Chan, T.U.; Christenson, E.; Cronk, R.D.; Leker, H.; Samani, D.; Apoya, P.; Lutz, A.; Bartram, J. Understanding handpump sustainability: Determinants of rural water source functionality in the Greater Afram Plains region of Ghana. Water Resour. Res. 2015, 51, 8431-8449. [CrossRef] [PubMed]

87. Pagano, A.; Giordano, R.; Portoghese, I.; Fratino, U.; Vurro, M. A Bayesian vulnerability assessment tool for drinking water mains under extreme events. Nat. Hazards 2014, 74, 2193-2227. [CrossRef]

88. Moglia, M.; Perez, P.; Burn, S. Assessing the likelihood of realizing idealized goals: The case of urban water strategies. Environ. Model. Softw. 2012, 35, 50-60. [CrossRef]

89. Moglia, M.; Sharma, A.K.; Maheepala, S. Multi-criteria decision assessments using Subjective Logic: Methodology and the case of urban water strategies. J. Hydrol. 2012, 452-453, 180-189. [CrossRef]

90. Kabir, G.; Tesfamariam, S.; Francisque, A.; Sadiq, R. Evaluating risk of water mains failure using a Bayesian belief network model. Eur. J. Oper. Res. 2015, 240, 220-234. [CrossRef]

91. Leu, S.-S.; Bui, Q.-N. Leak Prediction Model for Water Distribution Networks Created Using a Bayesian Network Learning Approach. Water Resour. Manag. 2016, 30, 2719-2733. [CrossRef]

92. Liedloff, A.C.; Woodward, E.L.; Harrington, G.A.; Jackson, S. Integrating indigenous ecological and scientific hydro-geological knowledge using a Bayesian Network in the context of water resource development. J. Hydrol. 2013, 499, 177-187. [CrossRef]

93. Barron, J.; Kemp-Benedict, E.; Morris, J.; de Bruin, A.; Wang, G.; Fencl, A. Mapping the potential success of agricultural water management interventions for smallholders: Where are the best opportunities? Water Resour. Rural Dev. 2015, 6, 24-49. [CrossRef]

94. Cain, J.D.; Jinapala, K.; Makin, I.W.; Somaratna, P.G.; Ariyaratna, B.R.; Perera, L.R. Participatory decision support for agricultural management. A case study from Sri Lanka. Agric. Syst. 2003, 76, 457-482.

95. Maleksaeidi, H.; Ranjbar, S.; Eskandari, F.; Jalali, M.; Keshavarz, M. Vegetable farmers' knowledge, attitude and drivers regarding untreated wastewater irrigation in developing countries: A case study in Iran. J. Clean. Prod. 2018, 202, 863-870. [CrossRef]

96. Andriyas, S.; McKee, M. Development of a Bayesian Belief Network Model Framework for Analyzing Farmers' Irrigation Behavior. J. Agric. Sci. 2015, 7, 1. [CrossRef]

97. Robertson, D.; Wang, Q.J. Bayesian networks for decision analyses: An application to irrigation system selection. Aust. J. Exp. Agric. 2004, 44, 145-150. [CrossRef]

98. Rahman, M.M.; Hagare, D.; Maheshwari, B. Framework to assess sources controlling soil salinity resulting from irrigation using recycled water: An application of Bayesian Belief Network. J. Clean. Prod. 2014, 105, 406-419. [CrossRef]

99. Sherafatpour, Z.; Roozbahani, A.; Hasani, Y. Agricultural Water Allocation by Integration of Hydro-Economic Modeling with Bayesian Networks and Random Forest Approaches. Water Resour. Manag. 2019, 33, 2277-2299. [CrossRef]

100. Quinn, J.M.; Monaghan, R.M.; Bidwell, V.J.; Harris, S.R. A Bayesian Belief Network approach to evaluating complex effects of irrigation-driven agricultural intensification scenarios on future aquatic environmental and economic values in a New Zealand catchment. Mar. Freshw. Res. 2013, 64, 460-474. [CrossRef]

101. Wang, G.; Xia, J.; Chen, J. Quantification of effects of climate variations and human activities on runoff by a monthly water balance model: A case study of the Chaobai River basin in northern China. Water Resour. Res. 2009, 45. [CrossRef]

102. Mamitimin, Y.; Feike, T.; Doluschitz, R. Bayesian network modeling to improve water pricing practices in northwest China. Water 2015, 7, 5617-5637. [CrossRef]

103. Castelletti, A.; Soncini-Sessa, R. Bayesian Networks and participatory modelling in water resource management. Environ. Model. Softw. 2007, 22, 1075-1088. [CrossRef]

104. Saravanan, V.S. Negotiating participatory irrigation management in the Indian Himalayas. Agric. Water Manag. 2010, 97, 651-658. [CrossRef]

105. Johns, A.F.; Graham, S.E.; Harris, M.J.; Markiewicz, A.J.; Stinson, J.M.; Landis, W.G. Using the Bayesian network relative risk model risk assessment process to evaluate management alternatives for the South River and upper Shenandoah River, Virginia. Integr. Environ. Assess. Manag. 2017, 13, 100-114. [CrossRef]

106. Stewart-Koster, B.; Bunn, S.E.; MacKay, S.J.; Poff, N.L.; Naiman, R.J.; Lake, P.S. The use of Bayesian networks to guide investments in flow and catchment restoration for impaired river ecosystems. Freshw. Biol. 2010, 55, 243-260. [CrossRef] 
107. Hjerppe, T.; Taskinen, A.; Kotamäki, N.; Malve, O.; Kettunen, J. Probabilistic Evaluation of Ecological and Economic Objectives of River Basin Management Reveals a Potential Flaw in the Goal Setting of the EU Water Framework Directive. Environ. Manag. 2017, 59, 584-593. [CrossRef]

108. Leigh, C.; Stewart-Koster, B.; Sheldon, F.; Burford, M.A. Understanding multiple ecological responses to anthropogenic disturbance: Rivers and potential flow regime change. Ecol. Appl. 2012, 22, 250-263. [CrossRef]

109. Shenton, W.; Hart, B.T.; Chan, T.U. A Bayesian network approach to support environmental flow restoration decisions in the Yarra River, Australia. Stoch. Environ. Res. Risk Assess. 2014, 28, 57-65. [CrossRef]

110. Allan, J.D.; Yuan, L.L.; Black, P.; Stockton, T.; Davies, P.E.; Magierowski, R.H.; Read, S.M. Investigating the relationships between environmental stressors and stream condition using Bayesian belief networks. Freshw. Biol. 2012, 57 (Suppl. 1), 58-73. [CrossRef]

111. Morrison, R.R.; Stone, M.C. Spatially implemented Bayesian network model to assess environmental impacts of water management. Water Resour. Res. 2014, 50, 8107-8124. [CrossRef]

112. Calder, I.; Gosain, A.; Rao, M.S.R.M.; Batchelor, C.; Garratt, J.; Bishop, E. Watershed development in India. 2. New approaches for managing externalities and meeting sustainability requirements. Environ. Dev. Sustain. 2007, 10, 427-440.

113. Borsuk, M.E.; Schweizer, S.; Reichert, P. A Bayesian network model for integrative river rehabilitation planning and management. Integr. Environ. Assess. Manag. 2012, 8, 462-472. [CrossRef]

114. Ropero, R.F.; Rumí, R.; Aguilera, P.A. Modelling relationships between socioeconomy, landscape and water flows in Mediterranean agroecosystems: A case study in Adra catchment (Spain) using Bayesian networks. Environ. Ecol. Stat. 2019, 26, 47-86. [CrossRef]

115. Chan, T.U.; Hart, B.T.; Kennard, M.J.; Pusey, B.J.; Shenton, W.; Douglas, M.M.; Valentine, E.; Patel, S. Bayesian network models for environmental flow decision making in the Daly River, Northern Territory, Australia. River Res. Appl. 2012, 28, 283-301. [CrossRef]

116. Varis, O.; Rahaman, M.M.; Kajander, T. Fully connected Bayesian belief networks: A modeling procedure with a case study of the Ganges river basin. Integr. Environ. Assess. Manag. 2012, 8, 491-502. [CrossRef]

117. Tattari, S.; Schultz, T.; Kuussaari, M. Use of belief network modelling to assess the impact of buffer zones on water protection and biodiversity. Agric. Ecosyst. Environ. 2003, 96, 119-132. [CrossRef]

118. Alameddine, I.; Cha, Y.; Reckhow, K.H. An evaluation of automated structure learning with Bayesian networks: An application to estuarine chlorophyll dynamics. Environ. Model. Softw. 2011, 26, 163-172. [CrossRef]

119. Couture, R.-M.; Moe, S.J.; Lin, Y.; Kaste, Ø.; Haande, S.; Lyche Solheim, A. Simulating water quality and ecological status of Lake Vansjø, Norway, under land-use and climate change by linking process-oriented models with a Bayesian network. Sci. Total Environ. 2018, 621, 713-724. [CrossRef]

120. Qian, S.S.; Miltner, R.J. A continuous variable Bayesian networks model for water quality modeling: A case study of setting nitrogen criterion for small rivers and streams in Ohio, USA. Environ. Model. Softw. 2015, 69, 14-22. [CrossRef]

121. Wijesiri, B.; Liu, A.; Deilami, K.; He, B.; Hong, N.; Yang, B.; Zhao, X.; Ayoko, G.; Goonetilleke, A. Nutrients and metals interactions between water and sediment phases: An urban river case study. Environ. Pollut. 2019, 251, 354-362. [CrossRef]

122. Borsuk, M.E.; Stow, C.A.; Reckhow, K.H. Integrated approach to total maximum daily load development for Neuse River Estuary using Bayesian probability network model (Neu-BERN). J. Water Resour. Plan. Manag. 2003, 129, 271-282. [CrossRef]

123. Borsuk, M.E.; Stow, C.A.; Reckhow, K.H. A Bayesian network of eutrophication models for synthesis, prediction, and uncertainty analysis. Ecol. Model. 2004, 173, 219-239. [CrossRef]

124. Nash, D.; Hannah, M. Using Monte-Carlo simulations and Bayesian Networks to quantify and demonstrate the impact of fertiliser best management practices. Environ. Model. Softw. 2011, 26, 1079-1088. [CrossRef]

125. McDowell, R.W.; Nash, D.; George, A.; Wang, Q.J.; Duncan, R. Approaches for quantifying and managing diffuse phosphorus exports at the farm/small catchment scale. J. Environ. Qual. 2009, 38, 1968-1980. [CrossRef]

126. Sperotto, A.; Molina, J.L.; Torresan, S.; Critto, A.; Pulido-Velazquez, M.; Marcomini, A. A Bayesian Networks approach for the assessment of climate change impacts on nutrients loading. Environ. Sci. Policy 2019, 100, 21-36. [CrossRef] 
127. Sušnik, J.; Molina, J.L.; Vamvakeridou-Lyroudia, L.S.; Savić, D.A.; Kapelan, Z. Comparative Analysis of System Dynamics and Object-Oriented Bayesian Networks Modelling for Water Systems Management. Water Resour. Manag. 2013, 27, 819-841. [CrossRef]

128. Asadilour, M.; Kaveh, F.; Manshuri, M.; Khosrojerdi, A. Developing decision support tools for optimum domestic management by bayesian belief networks in tehran, Iran. Adv. Environ. Biol. 2012, 6, $286-296$.

129. Geraldi, M.S.; Ghisi, E. Short-term instead of long-term rainfall time series in rainwater harvesting simulation in houses: An assessment using Bayesian Network. Resour. Conserv. Recycl. 2019, 144, 1-12. [CrossRef]

130. Molina, J.L.; Bromley, J.; García-Aróstegui, J.L.; Sullivan, C.; Benavente, J. Integrated water resources management of overexploited hydrogeological systems using Object-Oriented Bayesian Networks. Environ. Model. Softw. 2010, 25, 383-397. [CrossRef]

131. Said, A.; Stevens, D.K.; Sehlke, G. Physical and Economic Sustainability of Water: New Approach Using the Case of the Big Lost River, Idaho. Environ. Dev. Sustain. 2005, 7, 453-464. [CrossRef]

132. Varis, O.; Kuikka, S. BENE-EIA: A Bayesian approach to expert judgment elicitation with case studies on climate change impacts on surface waters. Clim. Chang. 1997, 37, 539-563. [CrossRef]

133. Mediero, L.; Garrote, L.; Martín-Carrasco, F. A probabilistic model to support reservoir operation decisions during flash floods. Hydrol. Sci. J. 2010, 52, 523-537. [CrossRef]

134. Malekmohammadi, B.; Kerachian, R.; Zahraie, B. Developing monthly operating rules for a cascade system of reservoirs: Application of Bayesian Networks. Environ. Model. Softw. 2009, 24, 1420-1432. [CrossRef]

135. Ropero, R.F.; Flores, M.J.; Rumí, R.; Aguilera, P.A. Applications of hybrid dynamic Bayesian networks to water reservoir management. Environmetrics 2017, 28, e2432. [CrossRef]

136. Kim, K.; Lee, S.; Jin, Y.; Kwanghoon, K.; Youngkyu, J.; Sangho, L. Forecasting Quarterly Inflow to Reservoirs Combining a Copula-Based Bayesian Network Method with Drought Forecasting. Water 2018, 10, 233.

137. Landuyt, D.; Lemmens, P.; D’Hondt, R.; Broekx, S.; Liekens, I.; De Bie, T.; Declerck, S.A.J.; De Meester, L.; Goethals, P.L.M. An ecosystem service approach to support integrated pond management: A case study using Bayesian belief networks-Highlighting opportunities and risks. J. Environ. Manag. 2014, 145, $79-87$. [CrossRef]

138. Chen, J.; Zhong, P.-A.; An, R.; Zhu, F.; Xu, B. Risk analysis for real-time flood control operation of a multi-reservoir system using a dynamic Bayesian network. Environ. Model. Softw. 2019, 111, 409-420. [CrossRef]

139. Cheon, S.P.; Kim, S.; Kim, J.; Kim, C. Learning Bayesian networks based diagnosis system for wastewater treatment process with sensor data. Water Sci. Technol. 2008, 58, 2381-2393. [CrossRef]

140. Li, D.; Yang, H.Z.; Liang, X.F. Prediction analysis of a wastewater treatment system using a Bayesian network. Environ. Model. Softw. 2013, 40, 140-150. [CrossRef]

141. Inman, D.; Blind, M.; Ribarova, I.; Krause, A.; Roosenschoon, O.; Kassahun, A.; Scholten, H.; Arampatzis, G.; Abrami, G.; McIntosh, B.; et al. Perceived effectiveness of environmental decision support systems in participatory planning: Evidence from small groups of end-users. Environ. Model. Softw. 2011, 26, 302-309. [CrossRef]

142. Bertone, E.; Sahin, O.; Stewart, R.A.; Zou, P.X.W.; Alam, M.; Hampson, K.; Blair, E. Role of financial mechanisms for accelerating the rate of water and energy efficiency retrofits in Australian public buildings: Hybrid Bayesian Network and System Dynamics modelling approach. Appl. Energy 2018, 210, 409-419. [CrossRef]

143. Chen, S.H.; Pollino, C.A. Good practice in Bayesian network modelling. Environ. Model. Softw. 2012, 37, 134-145. [CrossRef]

144. Fenton, N.; Neil, M. Making decisions: Using Bayesian nets and MCDA. Knowl. Based Syst. 2001, 14, 307-325. [CrossRef]

145. Khakzad, N.; Reniers, G. Application of Bayesian network and multi-criteria decision analysis to risk-based design of chemical plants. Chem. Eng. Trans. 2016, 48, 223-228.

146. Renooij, S. Probability elicitation for belief networks: Issues to consider. Knowl. Eng. Rev. 2001, 16, 255-269. [CrossRef]

(C) 2019 by the authors. Licensee MDPI, Basel, Switzerland. This article is an open access article distributed under the terms and conditions of the Creative Commons Attribution (CC BY) license (http://creativecommons.org/licenses/by/4.0/). 